SAKAI SAMBAYAN — Jurnal Pengabdian kepada Masyarakat

\title{
PELATIHAN PEMBUATAN OBAT KUMUR (MOUTHWASH) KAYU MANIS (Cinnamomum burmanii) DAN DAUN SIRIH (Piper betle L.) BAGI KELOMPOK KADER POSYANDU DESA HAJIMENA
}

\author{
Indra Gunawan*, Dias Ardini, Makhdalena \\ Jurusan Farmasi Politeknik Kesehatan Tanjungkarang, Bandar Lampung \\ Jl. Soekarno Hatta No. 1HajimenaBandar Lampung 35145 \\ Penulis Korespodensi : indragunawan@ poltekkes-tjk.ac.id
}

\begin{abstract}
Abstrak
Upaya peningkatan kesehatan yang ditujukan kepada Masyarakat di Desa Hajimena dilakukan mengikuti kebijakan pemerintah Kabupaten Lampung Selatan dan Provinsi Lampung dengan berbagai program peningkatan upaya kesehatan sunalah satu adalah kesehatan gigi dan mulut. Kegiatan pengabdian kepada masyarakat yang dilakukan Tim Dosen Program Studi DIII Farmasi melalui skema Program Kemitraan Masyarakat (PKM) telah memberikan kontribusi nyata terhadap peningkatan pengetahuan kelompok masyarakat (kader posyandu) Desa Hajimena, tentang pentingnya menjaga kesehatan mulut. Kegiatan pengabdian kepada masyarakat menghasilkan luaran berupa peningkatan pengetahuan Kader Posyandu Desa Hajimena terhadap penggunaan obat kumur (mouthwash) dengan nilai delta ( $\delta$ ) sebesar 19,5; peningkatan persepsi aroma nafas para kader setelah menggunakan obat kumur (mouthwash) dengan nilai delta ( $\delta$ ) sebesar 4,5; Kader Posyandu Desa Hajimena dapat membuat obat kumur alami secara mandiri memanfaatkan bahan dan peralatan sederhana dan terbentuknnya komunitas "HASBALUT" (Hajimena Bebas Bau Mulut). Evaluasi hasil kegiatan adalah masih diperlukannya pengembangan formula lebih lanjut terhadap produk obat kumur (mouthwash) kayu manis (Cinnamomum burmanii) dan daun sirih (Piper betle l.) hasil kegiatan pengabdian masyarakat menggunakan pengawet alami agar dapat digunakan dalam jangka waktu yang lebih lama.
\end{abstract}

Kata kunci: Obat Kumur, Kayu Manis, Daun Sirih, Hajimena

\section{Pendahuluan}

Bau mulut merupakan suatu keadaan dimana terciumnya bau mulut pada saat seseorang mengeluarkan nafas. Bau mulut berdampak pada terhentinya aktifitas sehari-hari. Bau mulut disebabkan dari mulut kering, stress, berpuasa, makan makanan yang berbau khas dan metabolisme lainnya. Keteraturan dalam mengatasi bau mulut memang belum menjadi kebiasaan bagi sebagian masyarakat, sehingga makan makanan yang berbau khas menjadi penyebab bau mulut.

Hajimena adalah desa yang berada di Kecamatan Natar Kabupaten Lampung Selatan. Letak geografi Desa Hajimena sebelah utara berbatasan dengan Desa Pemanggilan, selatan dengan Kelurahan Rajabasa, barat dengan Desa Kurungan Nyawa, dan timur dengan Desa Sidosari. Klasifikasi Desa Hajimena merupakan Desa Swakarya. Sumber penghasilan utama sebagian besar penduduk adalah jasa Desa Hajimena terdiri dari Rukun Warga sebanyak 14 RW dan Rukun Tetangga sebanyak 53 RT dan jumlah Dusun Di dalam Desa Hajimena sebanyak 7 Dusun, yang terdiri dari Dusun Induk Kampung, Way Layap, Sinar Jati, Bataranila, Perum Polri, Puri Sejahtera, dan Sidorejo.

Kementerian Kesehatan melalui Program Germas (Gerakan Masyarakat Sehat) yang pelaksanaannya dimulai dari keluarga karena keluarga adalah bagian terkecil dari masyarakat yang membentuk kepribadian. Satu dari kegiatan Germas adalah memeriksakan kesehatan secara rutin, salah satu memeriksakan kesehatan gigi dan mulut minimal setaip 6 (enam) bulan sekali yang dapat dimulai dari diri sendiri dan keluarga. Program Germas sebagai sebuah gerakan yang mengedepankan promotif dan preventif.

Berdasarkan hasil observasi yang dilakukan kelompok dosen Pengabdian kepada Masyarakat Jurusan Farmasi Poltekkes Tanjungkarang di Desa Hajimena terhadap kebersihan rongga mulut masih kurang begitu peduli, dan cenderung mengabaikan. Terlebih lagi upaya preventif dalam mencegah bau mulut sulit diakses oleh masyarakat dikarenakan 
harga obat kumur (mouthwash) sulit dijangkau masyarakat, khususnya masyarakat kelas bawah didominasi oleh buruh. Hal ini antara lain disebabkan oleh masyarakat kurangnya Perilaku Hidup Bersih dan Sehat (PHBS) terutama dalam perawatan rongga mulut. Bahkan sebagian besar cukup berkumur dengan air setelah gosok gigi.

Bentuk Program Kemitraan Masyarakat (PKM) yang diusulkan untuk menyelesaikan permasalahan yang menjadi prioritas adalah melalui pelatihan pembuatan obat kumur (mouthwash) kayu manis (Cinnamomum burmanii) dan daun sirih (Piper betle L.) bagi Kader Posyandu Desa Hajimena yang selaras dengan aplikasi hasil penelitian dosen di Jurusan Farmasi Politeknik Kesehatan Tanjungkarang yang berjudul "Studi Antibakteri Streptococcus mutans pada Formulasi Sediaan Mouthwash Minyak Atsiri Kayu Manis (Cinnamomum burmannii) dan Daun Sirih (Piper betle l)" pada Tahun 2017 dengan melakukan modifikasi dan penyesuaian dengan keadaan di masyarakat Desa Hajimena dan justifikasi tim pengabdian kepada masyarakat, yaitu:

a. Minimnya pengetahuan dan kesadaran masyarakat di Desa Hajimena terhadap upaya preventif dalam penyakit yang berhubungan dengan mulut dan gigi.

b. Harga produk obat kumur (mouthwash) di pasaran relatif mahal dan sulit dijangkau oleh masyarakat kelas bawah di Desa Hajimena.

Kader Posyandu di Desa Hajimena belum memiliki kemampuan dalam membuat sediaan alternatif obat kumur (mouthwash) yang lebih murah dan terjangkau.

\section{Bahan dan Metode}

Bahan-bahan dan metode yang digunakan pada kegiatan pengabdian kepada masyarakat disesuaikan dengan kebutuhan kegiatan yang dilakukan. Sesuai dengan hasil dan luaran kegiatan pengabdian kepada masyarakat, maka metode yang akandilakukan yaitu:

a. Ceramah dan diskusi

Metode ini dilakukan pada kegiatan Focus Group Discussion (FGD), penyuluhan penggunaan obat kumur (mouthwash), dan pembentukan komunitas Hajimena Bebas Bau Mulut "HASBALUT". Pada kegiatan ini dilakukan evaluasi penilaian terhadap kegiatan, yaitu pre-test dan pos-test untuk mengukur keberhasilan kegiatan yang telah dilakukan.

b. Demonstrasi pembuatan obat kumur
Metode ini dilakukan pada kegiatan pelatihan pembuatan obat kumur dengan memberikan torial dan praktek membuat obat kumur menggunakan bahan-bahan dan peralatan yang ekonomis dan mudah didapatkan di lingkungan sekitar rumah, yaitu:

1) Bahan-bahan yang digunakan meliputi; aquades, daun sirih, kayu manis, jeruk nipis, dan lemon

2) Peralatan yang digunakan meliputi; pada pembuatan obat kumur (mouthwash) meliputi: set kompor gas (kompor, regulator, dan tabung), panci penangas, pisau, talenan, botol, saringan kain, timbangan, dan gelas ukur.

Keseluruhan bahan-bahan dan peralatan yang digunakan pada kegiatan berasal dari Tim pengabmas yang dihibahakan kepada Kader Posyandu Desa Hajimena yang diwakili oleh Ketua Tim PKK Desa Hajimena sebagai stimulus awal untuk selanjutnya dapat dimanfaatkan untuk diseminasi oleh para kader posyandu di masyarakat.

\section{Hasil dan Pembahasan}

Hasil kegiatan pengabdian masyarakat dengan skema PKM di Desa Hajimena adalah peningkatan pengetahuan kader posyandu terhadap kesehatan gigi dan mulut khususnya untuk mencegah gangguan bau mulut dan pemberdayaan kader posyandu dalam membuat sediaan obat kumur (mouthwash) yang ekonomis, aman, dan mudah digunakan. Adapun kegiatan yang telah dihasilkan, yaitu:

a. Focus Group Discussion (FGD)

Pada kegiatan Focus Group Discussion (FGD) para kader posyandu Desa Hajimena sangat antusias dalam melakukan (FGD) tentang rencana kegiatan selanjutnya. Para kader memberikan beberapa saran terkait kegiatan penyuluhan, sebagai berikut;

1) Saran waktu pelaksanaan kegiatan penyuluhan dan lokasi yaitu pada Pukul 13.00 di Balai Desa Hajimena, dengan alasan pagi hari adalah waktu para kader melakukan peran sebagai ibu rumah tangga yang fokus terhadap kegaiatan mengurus rumah dan keluarga. Pemilihan lokasi kegiatan selanjutnya tetap dilaksanakan di Balai Desa adalah dikarenakan lokasi yang paling mudah dijangkau oleh para kader serta fasilitas dan ruangan yang sangat memadai

2) Saran materi penyuluhan untuk lebih mengedepankan kesederhanaan dalam penyajian, visual yang menarik, poin-poin penting dan krusial terkait penggunaan obat 
kumur, serta terdapat alat untuk penguji tingkat pemahaman para kader sebelum dan setelah kegiatan penyuluhan.

3) Saran produk obat kumur yang nantinya akan dilakukan pelatihan obat kumur (mouthwash) diharapkan menggunakan bahan alam yang mudah didapat, sederhana dalam pembuatannya, dam memiliki rasa yang ringan ketika digunakan.

b. Pada kegiatan penyuluhan kepada Kader Posyandu Desa Hajimena mengenai pentingnya penggunaan obat kumur (mouthwash) untuk menjaga kesehatan mulut sehingga terbebas dari gangguan bau mulut. Hasil kegiatan ini adalah pengetahuan awal rata-rata Kader Posyandu Desa Hajimena sebanyak 20 orang masih cukup rendah yaitu 48. Range penilaian berkisar antara 0-100 dengan yaitu dengan memberikan 10 soal pre-test dengan ketentuan tiap soal bernilai 10 kemudian menghitung jawaban yang benar dari masing-masing. Hasil pre-test menggambarkan kondisi masyarakat di masing-masing dusun yang masih memerlukan sosialisasi untuk meningkatkan pengetahuan pentingnya penggunaan obat kumur (mouthwash) untuk menjaga kesehatan mulut. Penyuluhan mengenai pentingnya penggunaan obat kumur (mouthwash) untuk menjaga kesehatan mulut dilakukan oleh langsung oleh kelompok dosen dan dibantu oleh perwakilan mahasiswa tingkat akhir Jurusan Farmasi Politeknik Kesehatan Tanjungkarang. Kelompok dosen memberikan pengetahuan penggunaan obat bebas dan obat bebas terbatas terhadap 20 orang Kader Posyandu yang hadir yang merupakan perwakilan masyarakat di masing-masing dusun. Proses sosialisasi diawali dengan pemaparan secara singkat tentang pengetahuan dalam menjaga kesehatan gigi dan mulut, khususnya pencegahan bau mulut, kemudian dilanjutkan tentang materi product knowledge produk dan komposisi obat kumur (mouthwash) dan macammacam jenis dan kegunaannya. Setelah seluruh kegiatan penyuluhan dilakukan maka kegiatan akhir adalah pemberian soal post-test kepada para kelompok kader yaitu dengan memberikan 10 soal post-test dengan ketentuan tiap soal bernilai 10 kemudian menghitung jawaban yang benar dari masing-masing dengan hasil rata-rata nilai 67,5. Hasil pre-test dan post-test memberikan gambaran secara umum, bahwa terjadi peningkatan pengetahuan Kader Posyandu Desa Hajimena terhadap penggunaan obat kumur (mouthwash) cukup signifikan dengan nilai delta $(\delta)$ sebesar 19,5 seperti terlihat pada Tabel. 3.1

Tabel 1. Perolehan Nilai Rata-rata Pre-test dan Post-test Pengetahuan Kader Posyandu

\begin{tabular}{|c|c|c|c|c|}
\hline \multirow[b]{2}{*}{ No } & \multirow[b]{2}{*}{$\begin{array}{l}\text { Inisial } \\
\text { Kader }\end{array}$} & \multicolumn{2}{|c|}{ Nilai } & \multirow{2}{*}{$\begin{array}{c}\text { Delta } \\
(\delta)\end{array}$} \\
\hline & & $\begin{array}{c}\text { Pre- } \\
\text { test }\end{array}$ & $\begin{array}{c}\text { Post- } \\
\text { test }\end{array}$ & \\
\hline 1. & SM & 40 & 40 & 0 \\
\hline 2. & MI & 40 & 60 & 20 \\
\hline 3. & TK & 80 & 70 & -10 \\
\hline 4. & SH & 80 & 80 & 0 \\
\hline 5. & SR & 40 & 60 & 20 \\
\hline 6. & JW & 50 & 70 & 20 \\
\hline 7. & ST & 40 & 50 & 10 \\
\hline 8. & DS & 40 & 50 & 10 \\
\hline 9. & DM & 10 & 60 & 50 \\
\hline 10. & $\mathrm{RM}$ & 30 & 60 & 30 \\
\hline 11. & $\mathrm{NL}$ & 30 & 70 & 40 \\
\hline 12. & YW & 10 & 60 & 50 \\
\hline 13. & AS & 60 & 90 & 30 \\
\hline 14. & SW & 60 & 80 & 20 \\
\hline 15. & YP & 50 & 70 & 20 \\
\hline 16. & SU & 40 & 70 & 30 \\
\hline 17. & MR & 50 & 70 & 20 \\
\hline 18. & SA & 50 & 60 & 10 \\
\hline 19. & LM & 90 & 80 & -10 \\
\hline 20. & $\mathrm{LF}$ & 70 & 100 & 30 \\
\hline \multicolumn{2}{|c|}{ Rata-rata } & 48 & 67,5 & 19,5 \\
\hline
\end{tabular}

c. Pada kegiatan pelatihan pembuatan obat kumur (mouthwash) menggunakan bahan herbal yang ekonomis, mudah didapatkan, dan dapat dibuat secara mandiri. Hasil kegiatan ini para Kader Posyandu Desa Hajimena yang hadir sebanyak 39 orang. Kegiatan diawali dengan presentasi singkat bahan dan peralatan yang akan digunakan pada pembuatan obat kumur (mouthwash). Bahan-bahan yang digunakan pada pembuatan obat kumur (mouthwash) meliputi; Aquades, daun sirih, kayu manis, jeruk nipis dan lemon. Peralatan yang digunakan pada pembuatan obat kumur (mouthwash) meliputi; set kompor gas (kompor, regulator, dan tabung), panci penangas, pisau, talenan, botol, saringan kain, timbangan elektrik, dan gelas ukur. Seluruh bahan dan peralatan disiapakan langsung oleh Tim Pengabmas sekaligus sebagai stimulus tim pengabmas menghibahkannya kepada perwakilan kader. Para kader Posyandu berperan aktif selama acara berlangsung. Hal ini diperlihatkan oleh para kader Posyandu yang mengikuti jalannya acara sampai selesai, aktif 
bertanya selama workshop berlangsung, terutama berkaitan dengan hal teknis pembuatan obat kumur (mouthwash). Sebelum acara workshop obat kumur (mouthwash) dilaksanakan, Tim pengabmas melakukan penilaian terhadap persepsi aroma nafas para kader menggunakan instrumen Visual Analog Scale (VAS). Range penilaian berkisar antara 010 yaitu dengan memberikan kesempatan untuk para kader memberikan penilaian terhadap aroma nafas berupa titik menggunakan ballpoint di sepanjang garis VAS sepanjang $10 \mathrm{~mm}$. Hasil penilaian sebelum menggunakan obat kumur (mouthwash) menunjukkan hasil penilaian persepsi aroma nafas para kader kosyandu masih rendah dengan nilai rata-rata 3,4. Setelah seluruh kegiatan workshop obat kumur dilaksanakan, Tim pengabmas memberikan penilaian kembali terhadap persepsi aroma nafas para kader setelah menggunakan obat kumur (mouthwash) yaitu dengan memberikan titik menggunakan ballpoint di sepanjang garis VAS. Hasil penilaian sesudah menggunakan obat kumur (mouthwash) menunjukkan hasil penilaian persepsi aroma nafas para kader kosyandu cukup tinggi masih rendah dengan nilai rata-rata 7,9. Hasil penilaian sebelum dan sesudah menggunakan obat kumur (mouthwash) memberikan gambaran secara umum, bahwa terjadi peningkatan persepsi aroma nafas para kader yang cukup signifikan dengan nilai delta $(\delta)$ sebesar 4,5 seperti terlihat pada Tabel. 3.2

Tabel 2. Perolehan Nilai Rata-rata Pre-test Persepsi Aroma Nafas dan Post-test Kader Posyandu

\begin{tabular}{|c|c|c|c|c|}
\hline \multirow{2}{*}{ No } & \multirow{2}{*}{$\begin{array}{c}\text { Inisial } \\
\text { Kader }\end{array}$} & \multicolumn{2}{|c|}{$\begin{array}{c}\text { VAS } \\
\text { Persepsi Aroma } \\
\text { Nafas (cm) }\end{array}$} & \multirow{2}{*}{$\begin{array}{c}\text { Delta } \\
(\boldsymbol{\delta})\end{array}$} \\
\cline { 3 - 4 } & & TM & DM & \\
\hline 1. & SU & 4,8 & 8,1 & 3,3 \\
\hline 2. & SY & 4,1 & 10 & 5,9 \\
\hline 3. & AM & 4,2 & 8,6 & 4,4 \\
\hline 4. & ST & 5,5 & 8,7 & 3,2 \\
\hline 5. & SH & 4,2 & 8 & 3,8 \\
\hline 6. & ML & 5,2 & 7,7 & 2,5 \\
\hline 7. & WD & 3 & 6,1 & 3,1 \\
\hline 8. & MN & 4,1 & 6,8 & 2,7 \\
\hline 9. & RM & 2,1 & 7,2 & 5,1 \\
\hline 10. & SR & 2,4 & 7,5 & 5,1 \\
\hline 11. & IJ & 4 & 7,8 & 3,8 \\
\hline 12. & LF & 3,1 & 6,7 & 3,6 \\
\hline 13. & SN & 5 & 8 & 3 \\
\hline 14. & MW & 5 & 7,6 & 2,6 \\
\hline 15. & SL & 5,2 & 7,5 & 2,3 \\
\hline
\end{tabular}

\begin{tabular}{|c|c|c|c|c|}
\hline 16. & SI & 3,1 & 8,7 & 5,6 \\
\hline 17. & SN & 1,5 & 9,3 & 7,8 \\
\hline 18. & RW & 4,7 & 8,5 & 3,8 \\
\hline 19. & SU & 5 & 6,5 & 1,5 \\
\hline 20. & SM & 4,7 & 7,1 & 2,4 \\
\hline 21. & SA & 4,3 & 8.7 & 4,4 \\
\hline 22. & DM & 5,8 & 8.6 & 2,8 \\
\hline 23. & LM & 2,1 & 6 & 3,9 \\
\hline 24. & AT & 5,4 & 7 & 1,6 \\
\hline 25. & KW & 5 & 7,5 & 2,5 \\
\hline 26. & SW & 3 & 8,2 & 5,2 \\
\hline 27. & JA & 2,5 & 8 & 5,5 \\
\hline 28. & AN & 2,8 & 8,7 & 5,9 \\
\hline 29. & IW & 1,7 & 8,1 & 6,4 \\
\hline 30. & IM & 2 & 8,7 & 6,7 \\
\hline 31. & SN & 6,5 & 3,2 & $-3,3$ \\
\hline 32. & SI & 3,8 & 6 & 2,2 \\
\hline 33. & MA & 0 & 10 & 10 \\
\hline 34. & SY & 0,1 & 5 & 4,9 \\
\hline 35. & JW & 0,3 & 9,8 & 9,5 \\
\hline 36. & NR & 0,2 & 9,1 & 8,9 \\
\hline 37. & MH & 3,5 & 9,7 & 6,2 \\
\hline 38. & SP & 0 & 10 & 10 \\
\hline 39. & MY & 0,7 & 9,3 & 8,6 \\
\hline Rata-rata & $\mathbf{3 , 4}$ & $\mathbf{7 , 9}$ & $\mathbf{4 , 5}$ \\
\hline & & & & \\
\hline
\end{tabular}

Pada kegiatan pembentukan Komunitas "HASBALUT" (Hajimena Bebas Bau Mulut) yang dimotori oleh Kader Posyandu Desa Hajimena. Komunitas yang terbentuk merupakan wadah untuk mengakomodir antusiasme para kader dan kalangan masyarakat di Desa Hajimena serta tim pengabmas untuk memberikan kontribusi yang berkelanjutan peningkatan kesehatan mulut di wilayah Desa Hajimena. Komunitas dibentuk dengan anggota sebanyak 10 orang yang keseluruhannya berasal dari Kader Posyandu Desa Hajimena dengan Ketua Komunitas adalah Ketua Kader Posyandu Desa Hajimena yang sekaligus sebagai Ketua Tim Penggerak PKK Desa Hajimena.

\section{Kesimpulan}

Kesimpulan yang didapat pada kegiatan pengabdian masyarakat pelatihan pembuatan obat kumur (mouthwash) kayu manis (Cinnamomum burmanii) dan daun sirih (Piper betle l.) bagi kelompok Kader Posyandu Desa Hajimena adalah :

a. Pengetahuan Kader Posyandu Desa Hajimena terhadap penggunaan obat kumur (mouthwash) meningkat dengan nilai delta $(\delta)$ sebesar 19,5. 
b. Persepsi aroma nafas para kader meningkat setelah menggunakan obat kumur (mouthwash) hasil pelatihan dengan nilai delta $(\delta)$ sebesar 4,5.

c. Kader Posyandu Desa Hajimena dapat membuat obat kumur alami secara mandiri memanfaatkan bahan dan peralatan sederhana.

Terbentuknnya komunitas "HASBALUT" (Hajimena Bebas Bau Mulut).

\section{Ucapan Terima Kasih}

Kegiatan pengabdian kepada masyarakat pelatihan pembuatan obat kumur (mouthwash) kayu manis (Cinnamomum burmanii) dan daun sirih (Piper betle l.) bagi kelompok Kader Posyandu Desa Hajimena dapat terlaksana atas dukungan berbagai pihak. Ucapan terima kasih kami sampaikan kepada:

1. Kementerian Kesehatan Republik Indonesia atas dukungan pendanaan terhadap kegiatan.

2. Politeknik Kesehatan Tanjungkarang yang telah memfasilitasi kegiatan

Perangkat Desa dan Masyarakat Desa Hajimena yang turut mensukesekan kegiatan.

\section{Daftar Pustaka}

Agusta, Andria. 2000. Minyak Atsiri Tumbuhan Tropika Indonesia. Bandung : ITB Press,1-7.

Badan POM RI. 2004. Monografi Ekstrak Tumbuhan Obat Indonesia Vol.1. Jakarta: Badan POM. 159 Halaman.

Depkes RI. 1979. Farmakope Indonesia Edisi III. Jakarta: Departemen Kesehatan Republik Indonesia. 1031 Halaman.

Depkes RI. 1980. Materia Medika Indonesia Jilid IV. Jakarta: Dirjen Pengawasan Obat dan Makanan. 197 Halaman.

Gendrowati, Fitri. 2009. Tanaman Obat Keluarga (TOGA). Jakarta Timur : Padi Press 118 halaman.

Kemenkes RI. 2010. Suplement 1 Farmakope Herbal Indonesia. Jakarta: Kementrian Kesehatan RI, 152 halaman.

Marjoni, Riza. 2016. Dasar-dasar Fitokimia untuk diploma III Farmasi. Jakarta timur. 153 halaman.

Nalina, T and Rahim,Z.A.H.2007. The Crude Aqueos Extract Of Piper betle L And Its Antibacterial Effect Toward Streptococcus mutans. American journal of biotechnology and biochemistry 3 (1). 2001. 10-15.

Sastroamidjojo, Seno. 2001. Obat Asli Indonesia. Jakarta : Dian Rakyat. 132 halaman.

\section{Dokumentasi Kegiatan}

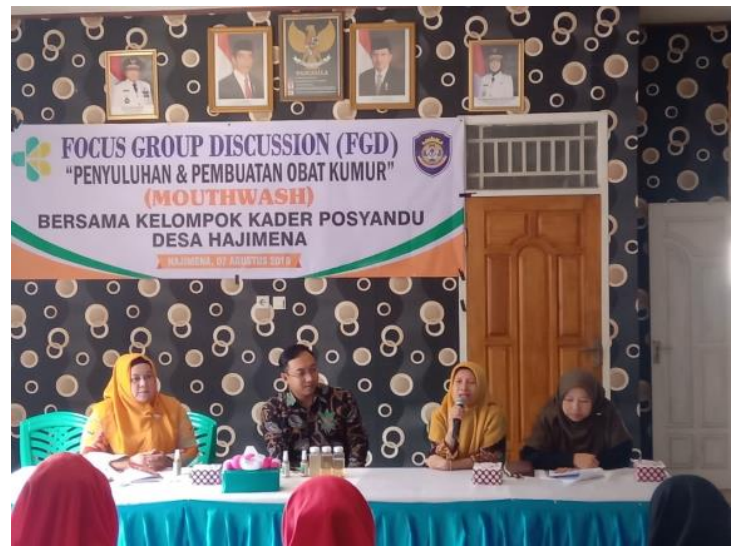

Gambar 1. FGD kader Posyandu Desa Hajimena

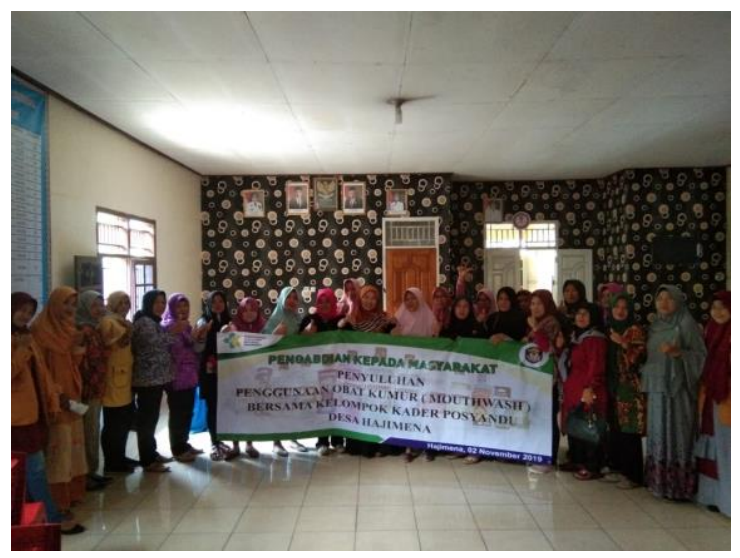

Gambar 2. Penyuluhan Penggunaan Obat Kumur bagi Kader Posyandu Desa Hajimena

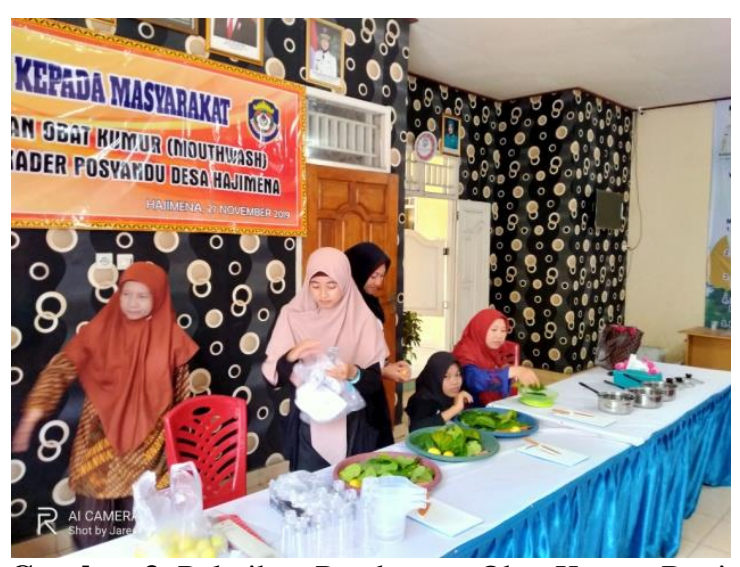

Gambar 3. Pelatihan Pembuatan Obat Kumur Bagi Kader Posyandu Desa Hajimena 


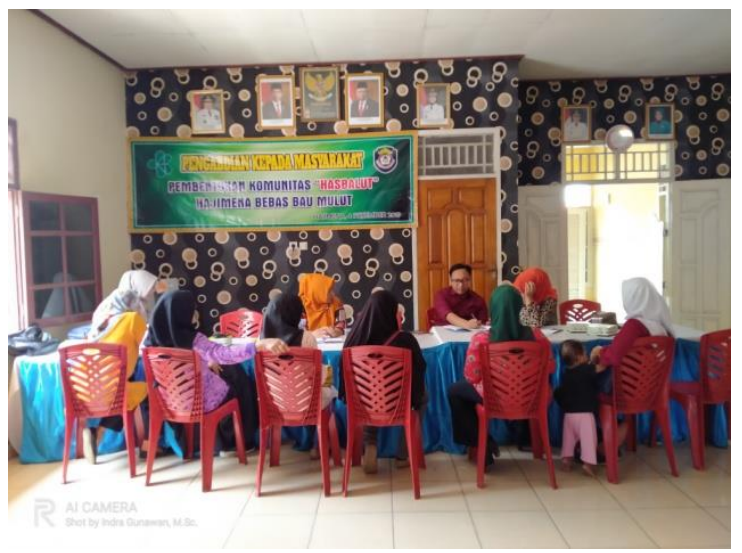

Gambar 4. Pembentukan Komunitas "Hasbalut" 